\title{
The $\mathrm{pH}$ and $\mathrm{pCO}_{2}$ dependence of sulfate reduction in shallow-sea hydrothermal $\mathrm{CO}_{2}$ - venting sediments (Milos Island, Greece)
}

\author{
Elisa Bayraktarov ${ }^{1}{ }^{\dagger}$, Roy E. Price ${ }^{2 \dagger}$,Timothy G. Ferdelman ${ }^{1,2}$ and Kai Finster ${ }^{3,4}$ \\ 1 Department of Biogeochemistry, Max Planck Institute for Marine Microbiology, Bremen, Germany \\ ${ }^{2}$ Center for Marine Environmental Sciences, Bremen, Germany \\ ${ }^{3}$ Department of Biosciences, Section for Microbiology, University of Aarhus, Aarhus C, Denmark \\ ${ }^{4}$ Department of Physics and Astronomy, Stellar Astrophysics Centre, University of Aarhus, Aarhus C, Denmark
}

\section{Edited by:}

Andreas Teske, University of North Carolina at Chapel Hill, USA

\section{Reviewed by:}

Tim Magnuson, Idaho State University, USA

Julia Maresca, University of

Delaware, USA

\section{${ }^{*}$ Correspondence:}

Elisa Bayraktarov, Department of

Ecology, Leibniz Center for Tropical Marine Ecology, Fahrenheitstraße 6, 28359 Bremen, Germany. e-mail: elisa.bayraktarov@ zmt-bremen.de

${ }^{t}$ Present address:

Elisa Bayraktarov, Department of Ecology, Leibniz Center for Tropical Marine Ecology, Fahrenheitstraße 6, 28359 Bremen, Germany;

Roy E. Price, Department of Earth Sciences, University of Southern California, Los Angeles, CA, USA.

\section{INTRODUCTION}

Microbial sulfate reduction (SR) is a dominant process for the anaerobic degradation of organic material in marine sediments where organic carbon or hydrogen gas serve as the electron donors and are oxidized to $\mathrm{CO}_{2}$ and water, while sulfate is reduced to hydrogen sulfide (Jørgensen, 1982). SR also plays an important role in deep-sea hydrothermal vent microbial processes, and has a significant impact on sulfur biogeochemistry at high temperatures (Jørgensen et al., 1992). The influence of temperature on SR is well documented (Isaksen et al., 1994; Knoblauch and Jørgensen, 1999; Finke and Jørgensen, 2008; Hubert et al., 2009). However, our understanding of the effects of $\mathrm{pH}$ and $\mathrm{CO}_{2}$, two important parameters that significantly impact microbial community structure and function is limited.

Submarine hydrothermal vents are well known for the extreme geochemical conditions that they impose on their inhabiting microbiota. Important selecting factors are low $\mathrm{pH}$, high temperatures and high metal and sulfide concentrations in the hydrothermal fluids (Jannasch and Mottl, 1985; Frank et al., 2013). Furthermore, steep temperature gradients demand adaptations to variable temperature regimes. Cultivation-based studies have shown that sulfur compounds are important substrates for microbes in hydrothermal vent systems (Jannasch and Mottl, 1985).

Most studies of sulfate reducing bacteria (SRB) have focused on environments at circumneutral $\mathrm{pH}$ including marine and freshwater sediments (Widdel, 1988; Hao et al., 1996). However, there is now increasing evidence for SR to occur also in low $\mathrm{pH}$ habitats, such as acidic lakes and rivers, acidic soils, peat lands, acid rock, or mine tailings (Koschorreck, 2008 and references therein). SR was also observed in hydrothermal systems where the $\mathrm{pH}$ is lowered due to $\mathrm{CO}_{2}$ venting (Amend et al., 2004) but further knowledge on the activity of these microbial communities is limited. SR has a low yield of metabolic energy (Widdel, 1988). However, surprisingly SRB are active under acidic conditions where additional energy requirements to keep an elevated intracellular $\mathrm{pH}$ (Martin, 1990; Lowe et al., 1993), the toxicity of metabolic products (e.g., $\mathrm{H}_{2} \mathrm{~S}$ or protonated fatty acids, Hao et al., 1996) and competition with other more resistant microbes (e.g., iron reducing bacteria or methanogens) may inhibit SR to occur (Koschorreck, 2008). Below a $\mathrm{pH}$ of 5 , the metabolic product of SR is exclusively present in its undissociated form $\mathrm{H}_{2} \mathrm{~S}$ which is considered as the most toxic form of sulfide (Moosa and Harrison, 2006). As uncharged gas, $\mathrm{H}_{2} \mathrm{~S}$ permeates the cell membrane where it 
can react with free metal ions and metal containing functional groups of the electron carrier system of the cell (Hao et al., 1996), amino acids and metabolic coenzymes inhibiting the functionality of the microbial cell (Koschorreck, 2008). Volatile fatty acids (VFA) are fermentation products of organic carbon and represent typical substrates of sulfate reducers. VFA exist as protonated organic acids under low $\mathrm{pH}$. In their protonated form they can diffuse through the cytoplasmic membrane and act as "uncouplers" (Bruun et al., 2010) leading to a collapse of the membrane potential (Baronofsky et al., 1984). In addition, protonated organic acids decrease the $\mathrm{pH}$ of the cytoplasm upon entering by diffusion. Free intracellular protons can impair processes such as DNA transcription, protein synthesis, and enzyme activities (Baker-Austin and Dopson, 2007). In nature, intermediates of fermentation, e.g., VFA and $\mathrm{H}_{2}$, are generally maintained at low concentrations, showing a close coupling of terminal oxidation to fermentation (Finke and Jørgensen, 2008) counteracting an accumulation of acid and a subsequent decrease in $\mathrm{pH}$.

In addition, $\mathrm{SR}$ at low $\mathrm{pH}$ is of special interest because this process can be applied for biogenic neutralization of acid rock drainage environments and for bioremediation (Kaksonen and Puhakka, 2007). The investigation of $\mathrm{CO}_{2}$ venting hydrothermal sediments is of particular interest, as they represent a system in which the degassing-effects of previously sequestered $\mathrm{CO}_{2}$ can be investigated (Shitashima et al., 2008). Based on all these implications further knowledge is necessary to understand the biological and chemical dynamics in acidified sediments.

This study was conducted on sediments collected from a shallow submarine hydrothermal vent system in the Aegean Sea near the island of Milos (Greece), and focuses on the effect of $\mathrm{pH}$ and $\mathrm{pCO}_{2}$ on the activity of SRB. By incubation experiments involving the addition of electron donors and at different $\mathrm{pH}$ and $\mathrm{pCO}_{2}$, SR activities of hydrothermally influenced sediments were compared to activities in control sediments with higher $\mathrm{pH}$ and no $\mathrm{CO}_{2}$ venting.

\section{MATERIALS AND METHODS STUDY SITE}

The study site $\left(36^{\circ} 40^{\prime} 25 \mathrm{~N}, 24^{\circ} 30^{\prime} 58 \mathrm{E}\right.$; Figure 1A) was located $\sim 1 \mathrm{~m}$ from an active gaseous hydrothermal vent system at $4.5 \mathrm{~m}$ water depth in Paleochori Bay, Milos Island, Greece. The bay is situated at the southeastern coast of Milos in the Aegean Sea (Figure 1B). Free gases sampled from the site (collected in 2011) had a mean gas composition of $92.5 \% \mathrm{CO}_{2}, 0.13 \% \mathrm{O}_{2}, 0.67 \% \mathrm{~N}_{2}$,

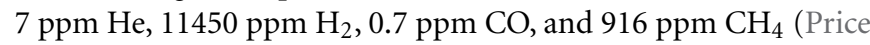
et al., 2013, this issue). These free gas values can be used as an approximation for the discharged gases of the seep. The vent sites displayed a characteristic zonation of colored surface deposits surrounding the gas outlets (Figure 2). The sediment next to the vent was covered by a layer of bright yellow-orange deposits containing the arsenic sulfide minerals similar to orpiment (Price et al., 2012). A zone covered by white flocculent material on top of black sediment termed "white zone" surrounded this area. The white precipitate consists of a mixture of amorphous silica and native S (Fitzsimons et al., 1997). It is assumed that this precipitate is associated with microbial mat communities (Dando et al., 1995; Fitzsimons et al., 1997). The white zone was surrounded by an area

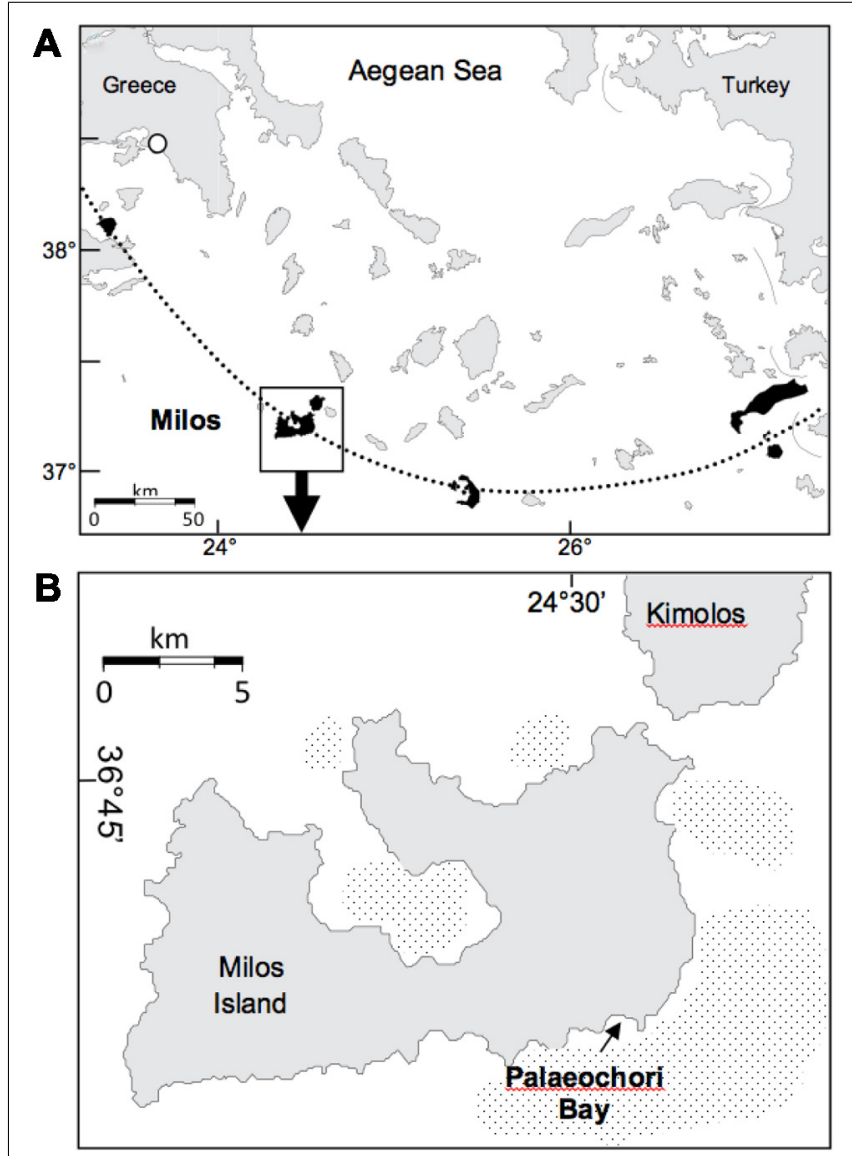

FIGURE 1 | (A) Location of Milos Island and other calc-alkaline volcanoes (shaded) along the Aegean Island Arc (dotted line). (B) Milos Island and the location of Palaeochori Bay. Stippled offshore areas around the island are mapped gas emissions by echo sounding (Dando et al., 1995). Maps modified from Price et al., 2012.

of gray sediment referred to as the "transition zone" and a brown background zone called the "brown zone" with hydrothermally unaffected sediment characteristics such as ambient temperature and $\mathrm{pH}$. Sediments from the brown zone were used as a control.

\section{SAMPLING}

Sampling was carried out along a transect through different sediment zones by SCUBA diving in August 2010. Sediments at increasing distance (ca. 1, 2, and $5 \mathrm{~m}$ ) from the gas emission zone were sampled underwater with $1 \mathrm{~L}$ preserving jars (Figure 2; J. WECK GmbH \& Co. KG, Wehr, Germany) containing a butyl rubber stopper which prevented the contamination of the sample with oxygen. Samples were maintained dark and cold during shipping. Temperature measurements were conducted in situ at a sediment depth of $\sim 10 \mathrm{~cm}$ with a digital thermometer in a custom underwater housing (Fisher Scientific, Germany). The $\mathrm{pH}$ measurements integrated over $60 \mathrm{~mL}$ of sediment pore water. Measurements were performed $\sim 1 \mathrm{~h}$ after sampling from a $10 \mathrm{~cm}$ sediment depth at the main sampling locations using $60 \mathrm{~mL}$ syringes elongated by tubing connected to long perforated pipette tips. Pore water from the white zone was sampled down 


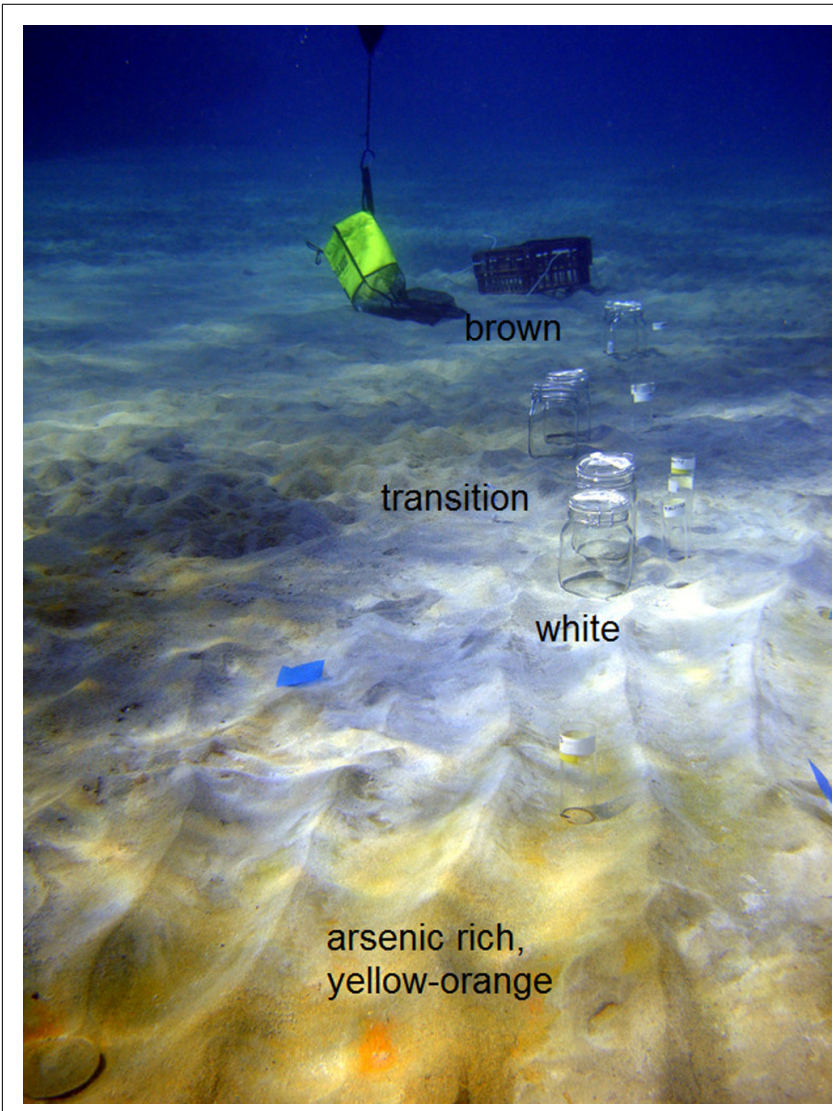

FIGURE 2 | Transect through the different zones of Paleochori Bay marked with sample bottles. Zones were divided in yellow-orange, white, transition, and brown. The yellow-orange zone was located adjacent to the venting site.

to $12 \mathrm{~cm}$ sediment depth at $2 \mathrm{~cm}$ resolution for analysis of sulfide, sulfate, alkalinity and $\mathrm{pH}$ using rhizon soil moisture samplers (5 and $10 \mathrm{~cm}$ rhizons, pore size: $0.1 \mathrm{~m}$, Rhizon core solution sampler (CSS), Rhizosphere Research Products, The Netherlands). For sulfide analysis, pore water samples were fixed with an equal volume of $50 \mathrm{mmol} \mathrm{L}^{-1}$ zinc acetate (ZnAc) solution.

\section{PHYSICOCHEMICAL MEASUREMENTS}

Pore water sulfide fixed with ZnAc was analyzed spectrophotometrically according to Cline (1969). Concentrations of $\mathrm{SO}_{4}^{2-}$ were measured on a Metrohm Compact 761 ion chromatograph equipped with a Metrohm Metrosep A column. The eluent was a $3.2 \mathrm{mmol} \mathrm{L}^{-1} \mathrm{Na}_{2} \mathrm{CO}_{3} / 1 \mathrm{mmol} \mathrm{L}{ }^{-1} \mathrm{NaHCO}_{3}$ solution

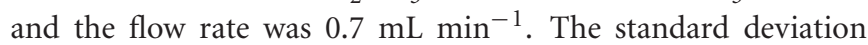
of repeated measurements was always below $2 \%$ of the measured concentration. Prior to measurement, samples were diluted 100 -fold with distilled water. Blanks were used for background corrections.

\section{MEDIUM}

Artificial seawater medium for SRB (modified from Widdel, 1988) contained (mmol per liter): $\mathrm{KBr}(0.756), \mathrm{KCl}(8.05) ; \mathrm{CaCl}_{2}{ }^{\star} 2 \mathrm{H}_{2} \mathrm{O}$ (10); $\mathrm{MgCl}_{2}{ }^{\star} 6 \mathrm{H}_{2} \mathrm{O}$ (27.89); $\mathrm{MgSO}_{4}{ }^{*} \mathrm{H}_{2} \mathrm{O}$ (11); $\mathrm{NaCl}$ (451);
$\mathrm{NH}_{4} \mathrm{Cl}$ (4.67) and $\mathrm{KH}_{2} \mathrm{PO}_{4}$ (1.47) and was prepared without the addition of $\mathrm{NaHCO}_{3}$ as buffering solution to allow for easier $\mathrm{pH}$ adjustment. For incubation experiments the $\mathrm{pH}$ was adjusted to values of $3,4,5,6$, and 7 with sterile $1 \mathrm{mmol} \mathrm{L}^{-1}$ phosphoric acid $\left(\mathrm{H}_{3} \mathrm{PO}_{4}\right)$ or $\mathrm{NaHCO}_{3}$ (Widdel, 1988) before sterilization for $25 \mathrm{~min}$ at $121^{\circ} \mathrm{C}$ and re-adjusted if necessary. Prior to sterilization, needles were inserted into the butyl stoppers of each medium bottle to allow escape of oxygen from the liquid at high temperature. The $75^{\circ} \mathrm{C}$ hot medium was allowed to cool down under constant stirring and flushing the headspace of the bottle with a mixture of $\mathrm{N}_{2} / \mathrm{CO}_{2}$ at a $9 / 1$ ratio(v/v). The salinity of the SRB-media was 33 .

\section{SULFATE REDUCTION RATE MEASUREMENTS}

To determine sulfate reduction rates (SRR) for the different incubation experiments, $20 \mu \mathrm{L}$ of ${ }^{35} \mathrm{~S}$-sulfate tracer containing $100 \mathrm{kBq}$ were injected into $15 \mathrm{~mL}$ Hungate tubes containing $2 \mathrm{~mL}$ homogenized sediment and $3 \mathrm{~mL}$ of SRB medium in 1:1.5 (v/v). Samples were incubated at 40 or $75^{\circ} \mathrm{C}$. Per experiment, three killed controls were prepared by transferring the sediment and the medium directly to Hungate tubes containing $5 \mathrm{~mL}$ of $20 \%$ (w/v) ZnAc solution in centrifuge tubes. The tubes were shaken and tracer was added to the killed slurries. Every sample was prepared in triplicate. Incubations were stopped by transferring the sediment slurries into centrifuge tubes containing $5 \mathrm{~mL}$ of a $20 \%$ (w/v) ZnAc solution.

Reduced inorganic sulfur compounds were removed from the fixed samples by single step cold acidic chromium distillation method as described by Fossing and Jørgensen (1989) and further modified by Kallmeyer et al. (2004). The ${ }^{35} \mathrm{~S}$ incorporated into the pool of total reduced inorganic sulfur was recovered as zinc sulfide in traps containing $7 \mathrm{~mL}$ of a $5 \%$ (w/v) ZnAc solution and finally counted in a scintillation counter (Packard Tri-Carb Liquid Scintillation Counter, MA, USA). SRR were determined as described in Kallmeyer et al. (2004). The porosity of each sediment type was determined by differential weighting of wet and dry sediment after drying for 2 days at $80^{\circ} \mathrm{C}$ to constant weight.

\section{INCUBATIONS}

All collected sediment samples were used for experiments on residual sulfate reducing activity 52 days after sampling as this was the time required for shipping of sampled material and installation of experimental setup. A pre-incubation for $18 \mathrm{~h}$ without tracer was followed by tracer incubation for $35 \mathrm{~h}$. Incubations were performed either at 40 or $75^{\circ} \mathrm{C}$. A SRB medium with $11 \mathrm{mmol} \mathrm{L}^{-1}$ of sulfate and $\mathrm{pH} 5.3$ was used to mimic the in situ characteristics of the white zone sediment.

A device for anaerobic slurry preparation and simultaneous $\mathrm{pH}$ measurement was constructed of sterilized material (15 min at $\left.121^{\circ} \mathrm{C}\right)$. Slurry of $1: 4(\mathrm{v} / \mathrm{v})$ ratio of sediment to medium was prepared and the $\mathrm{pH}$ was adjusted with phosphoric acid or $\mathrm{NaHCO}_{3}$. After $\mathrm{pH}$ adjustment, $5 \mathrm{~mL}$ of slurry were transferred into preflushed oxygen-free Hungate tubes. The headspace of each tube was flushed with a mixture of $\mathrm{N}_{2}$ and $\mathrm{CO}_{2}$ at a $9 / 1$ ratio (v/v) and the tube was sealed with a butyl rubber stopper and kept in place by a screw cap.

For experiments on stimulated SR, a mix of VFA (Widdel, 1988) was supplied to the sediment samples as additional electron 
donors. It contained formate, acetate, propionate, butyrate and succinate in equal-molar amounts providing a total fatty acid concentration of $1 \mathrm{~mol} \mathrm{~L}^{-1}$. The mixture of VFA was added with a $\mathrm{N}_{2} / \mathrm{CO}_{2}$-flushed $1 \mathrm{~mL}$ syringe through the butyl stopper of the slurry bottles to produce a final slurry concentration of $1 \mathrm{mmol} \mathrm{L}^{-1}$ VFA. The $\mathrm{pH}$ was re-adjusted for each slurry bottle after fatty acid addition. For each experiment with VFA-supplemented slurries, three incubations were prepared as killed controls. All experiments were carried out in triplicates.

For $\mathrm{pH}$ experiments, samples were incubated for $16-18 \mathrm{~h}$ at $40^{\circ} \mathrm{C}$ after a short pre-incubation. Pre-incubation time was calculated as the time required for $\mathrm{pH}$ adjustment and the distribution of slurry into Hungate tubes prior to incubation with radioactive tracer. Sample preparation was conducted at room temperature and was completed in less than $4 \mathrm{~h}$. For all incubation experiments, the surface sediment fractions $(0-5 \mathrm{~cm})$ of white and transition zone sediments and a deeper fraction $(5-10 \mathrm{~cm})$ of the brown zone sediment were used. For incubation experiments at $\mathrm{pH}$ of $3,4,5,6$, and 7, the phosphate buffering system, with $\mathrm{pK} a$ values $2.15,6.87$, and 12.33 (Perrin, 1972) was appropriate. Before and after each incubation experiment, the $\mathrm{pH}$ of each tube was measured after gentle mixing. For $\mathrm{pH}$ measurement prior to incubation, $200 \mu \mathrm{L}$ of the liquid were removed with a needle and a $\mathrm{N}_{2} / \mathrm{CO}_{2}$-flushed $1 \mathrm{~mL}$ syringe through the butyl stopper of the tube. The $\mathrm{pH}$ was measured after the incubation by inserting the $\mathrm{pH}$ electrode into each tube after gentle shaking. All $\mathrm{pH}$ values were determined in triplicates. The $\mathrm{pH}$ changed during the incubation between \pm 0.1 and $\pm 0.5 \mathrm{pH}$ units (horizontal error bars in Figure 4).

Additionally, incubation experiments were conducted to investigate the combined effects of $\mathrm{pH}$ and $\mathrm{pCO}_{2}$ on SR. Therefore, different $\mathrm{CO}_{2}$ partial pressures in the range of $0,1,2$, and 3 bar were applied after a pre-incubation for $12 \mathrm{~h}$ at $40^{\circ} \mathrm{C}$. Prior to incubation experiments, $\mathrm{CO}_{2}$ partial pressures were adjusted to the gas phase of tubes $(10 \mathrm{~mL}$ headspace in a total volume of $15 \mathrm{~mL})$ using a pressure reducer.

\section{STATISTICAL ANALYSES}

Arithmetic means and standard errors were calculated for each triplicate set of experiments and are represented by vertical error bars in the activity diagrams (Figures 4 and 5). Statistical analysis was performed with SigmaPlot, 12.0, Copyright (C) 2011 Systat Software, Inc. A One-Way-ANOVA was used to test for statistically significant differences between the groups considering a triplicate at a certain $\mathrm{pH}$ value $(3,4,5,6$, and 7$)$ or $\mathrm{CO}_{2}$ partial pressure $(0,1,2$, and 3 bar) as a group. The dependent variable was SRR. Only values above the reported detection limit of $0.04 \mathrm{nmol} \mathrm{SO} \mathrm{SO}_{4}^{2-} \mathrm{cm}^{-3} \mathrm{~d}^{-1}$ were taken into account and values below this limit were set to 0 . Degree of freedom df, $\mathrm{F}$ factor, and $P$-value (df, $\mathrm{F}$, and $\mathrm{P}$ ) are given. A Two-Way ANOVA was applied to test for differences between groups and treatment (untreated or supplemented sediment).

\section{RESULTS}

\section{GEOCHEMICAL CHARACTERIZATION}

In situ measurements of temperature and ex situ determination of $\mathrm{pH}$ demonstrated that the shallow-sea hydrothermal vent site constituted an extreme environment. The $\mathrm{pH}$ decreased with increasing proximity to the gas vent reaching values of 5.3 in the white and 7.6 in the pore water of brown zone sediment (zonation displayed in Figure 2). Temperatures measured at $10 \mathrm{~cm}$ sediment depth were $75^{\circ} \mathrm{C}$ in the white and $26^{\circ} \mathrm{C}$ in the brown zone sediment. Temperature and $\mathrm{pH}$ measurements were not conducted in the transition zone sediment. The pore water concentration of hydrogen sulfide increased from $553 \mu \mathrm{M}$ at a sediment depth of $2 \mathrm{~cm}$ to $608 \mu \mathrm{M}$ at $4 \mathrm{~cm}$; concomitantly, the sulfate concentration decreased from 11.3 to $10.5 \mathrm{mmol} \mathrm{L}^{-1}$ at the same depth.

The bulk seawater $\mathrm{pH}$ was 8.0 and the alkalinity $3.6 \mathrm{mmol} \mathrm{kg}^{-1}$. The $\mathrm{pH}$ in the white zone depth profile was between 5.2 and 5.3. Alkalinity decreased with depth from 2.1 to $1.1 \mathrm{mmol} \mathrm{kg}^{-1}$ in white sediment pore water (Price et al., 2012).

\section{SULFATE REDUCTION RATE MEASUREMENTS}

Sulfate reduction rates determined at $40^{\circ} \mathrm{C}$ in sediments that were collected close to the main venting site (white zone) were below $1 \mathrm{nmol} \mathrm{SO} \mathrm{SO}_{4}^{2-} \mathrm{cm}^{-3} \mathrm{~d}^{-1}$. At this temperature, SRR increased with distance from the gas discharge zone, reaching $24 \mathrm{nmol}$ $\mathrm{SO}_{4}^{2-} \mathrm{cm}^{-3} \mathrm{~d}^{-1}$ in surface sediment of the transition zone (Figure 3A). The highest activity at $40^{\circ} \mathrm{C}$ was found within the brown zone sediment (control) with $35 \mathrm{nmol} \mathrm{SO}_{4}^{2-} \mathrm{cm}^{-3} \mathrm{~d}^{-1}$. SR was mostly inhibited at $75^{\circ} \mathrm{C}$ (Figure 3B). However, SR was measurable in brown zone sediment at $75^{\circ} \mathrm{C}$, with a SRR of $2.4 \mathrm{nmol}$ $\mathrm{SO}_{4}^{2-} \mathrm{cm}^{-3} \mathrm{~d}^{-1}$, which is approximately 15 times less than the rate measured at $40^{\circ} \mathrm{C}$. As SRR were below the detection limit of our method at $75^{\circ} \mathrm{C}$, all further incubation experiments were conducted at an intermediate temperature of $40^{\circ} \mathrm{C}$, which represents approximately the average found in hydrothermally influenced sediments.

\section{THE pH EFFECT ON SULFATE REDUCTION}

The SRR increased with $\mathrm{pH}$ until they reached a $\mathrm{pH}$ optimum $\left(\mathrm{pH}_{\mathrm{opt}}\right)$ defined as the $\mathrm{pH}$ at which the highest SRR was measured (Figures 4A-C). The different sediment types of Paleochori Bay varied in the level of SR activity, its $\mathrm{pH}$ dependence and $\mathrm{pH}_{\text {opt }}$.

Among all tested sediments, the white zone sediment showed the lowest SR activity. The rates were statistically different for $\mathrm{pH}$ values between 3 and $7(d f=4, F=17.47, P<0.001)$. Highest rates were measured at $\mathrm{pH} 6.3$ with an arithmetic average of $0.2 \mathrm{nmol}$ $\mathrm{SO}_{4}^{2-} \mathrm{cm}^{-3} \mathrm{~d}^{-1}$ (Figure 4A). At $\mathrm{pH} 7 \mathrm{SRR}$ were below the detection limit. This was also the case at $\mathrm{pH}<4$. At $\mathrm{pH}$ of 4.7 the rates were close to detection limit. The addition of $1 \mathrm{mmol} \mathrm{L}^{-1}$ of VFA to white zone sediment samples decreased SRR to below the detection limit at $\mathrm{pH}$ values $<4.5$. The $\mathrm{pH}_{\text {opt }}$ remained at $\mathrm{pH} 6.4$ but the corresponding SRR showed an increasing trend from 0.2 to $0.3 \mathrm{nmol} \mathrm{SO}_{4}^{2-} \mathrm{cm}^{-3} \mathrm{~d}^{-1}$ after VFA addition. SR activity could also be detected at $\mathrm{pH} 7.3$ with a rate of $0.1 \mathrm{nmol} \mathrm{SO}_{4}^{2-} \mathrm{cm}^{-3} \mathrm{~d}^{-1}$ after VFA addition. In summary, the white zone sediment showed the highest SRR at pH values between 6.3 and 6.4 in treatments, both with and without VFA-amendment.

The transition zone sediments showed significantly different SRR for all $\mathrm{pH}$ values $(d f=4, F=19.89, P<0.001$; Figure $4 \mathrm{~B})$. The highest rate was measured between $\mathrm{pH} 5.5$ and 6.3 with rates of $6.5 \mathrm{nmol} \mathrm{SO} \mathrm{ng}^{2-} \mathrm{cm}^{-3} \mathrm{~d}^{-1}$. The SRR measured at $\mathrm{pH}_{\mathrm{opt}}$ were 


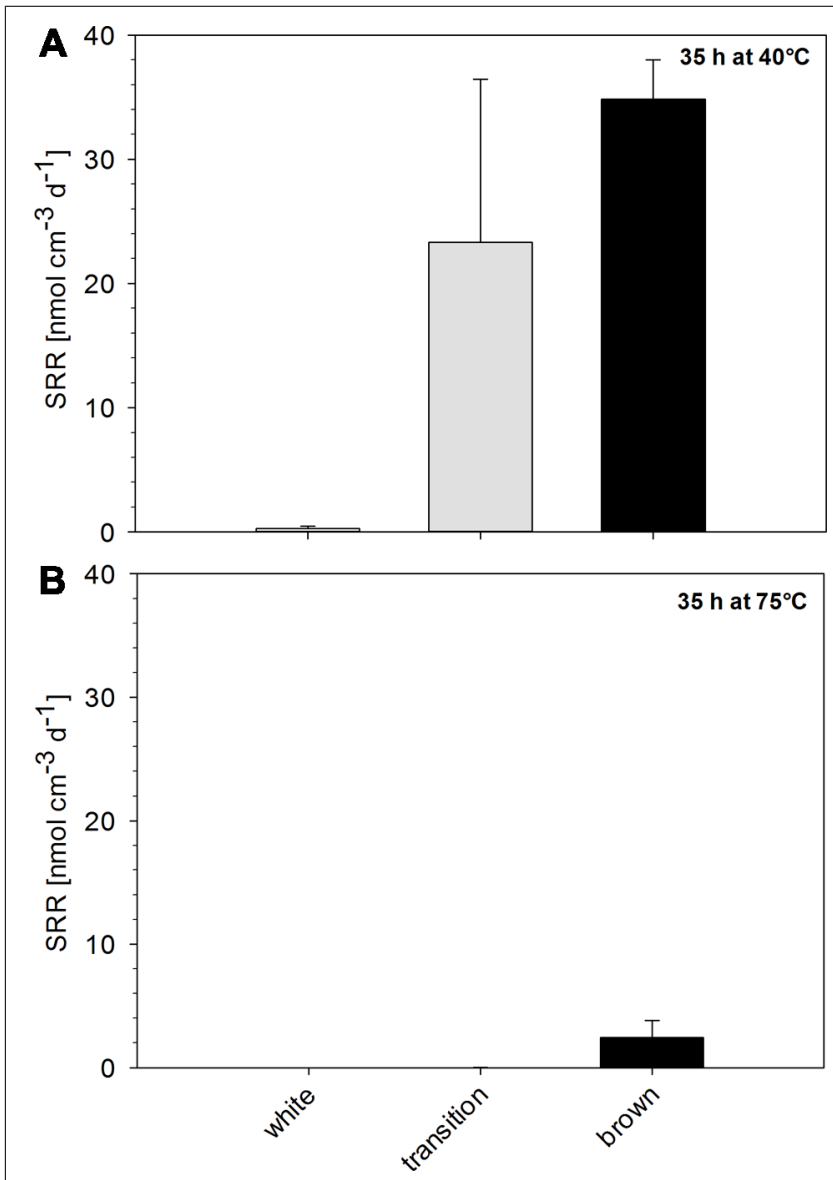

FIGURE 3 | Residual sulfate reduction rate of Paleochori Bay sediments after incubation for $35 \mathrm{~h}$ at a temperature of $(\mathrm{A}) 40^{\circ} \mathrm{C}$ and $(\mathrm{B}) 75^{\circ} \mathrm{C}$.

40 times higher in the transition zone as compared to the highest rates in white zone sediments. Furthermore, measurable rates at $\mathrm{pH}<5$ were found with $1.9 \mathrm{nmol} \mathrm{SO}{ }_{4}^{2-} \mathrm{cm}^{-3} \mathrm{~d}^{-1}$ at a $\mathrm{pH}$ 4.6. At a $\mathrm{pH}<4$ the rates were below the detection limit. At $\mathrm{pH} 7.3$ SRR were four times lower than at $\mathrm{pH}_{\mathrm{opt}}$. After VFA-addition an increase in SRR could be identified as compared to the untreated slurries $(d f=1, F=5.02, P=0.037)$ and the highest rates increased significantly from $6.5 \mathrm{nmol} \mathrm{SO}{ }_{4}^{2-} \mathrm{cm}^{-3} \mathrm{~d}^{-1}$ (-VFA) to $9.0 \mathrm{nmol}$ $\mathrm{SO}_{4}^{2-} \mathrm{cm}^{-3} \mathrm{~d}^{-1}$ (+VFA) at $\mathrm{pH}_{\mathrm{opt}}$ of 6.1. The SRR at $\mathrm{pH} \leq 5.5$ was slightly increased from $6.5 \mathrm{nmol} \mathrm{SO}{ }_{4}^{2-} \mathrm{cm}^{-3} \mathrm{~d}^{-1}$ at a $\mathrm{pH}$ of 5.5 to a rate of $7.6 \mathrm{nmol} \mathrm{SO} \mathrm{Sm}^{2-} \mathrm{cm}^{-3} \mathrm{~d}^{-1}$ at $\mathrm{pH} 5.2$ after amendment. At $\mathrm{pH}<4$, SR could no longer be detected. At $\mathrm{pH}>7$ the SRR were only increased from $1.6 \mathrm{nmol} \mathrm{SO}{ }_{4}^{2-} \mathrm{cm}^{-3} \mathrm{~d}^{-1}$ without amendment to $2.4 \mathrm{nmol} \mathrm{SO}{ }_{4}^{2-} \mathrm{cm}^{-3} \mathrm{~d}^{-1}$ after addition of VFA.

Sulfate reduction rates in the brown zone sediment were $2.3 \mathrm{nmol} \mathrm{SO} \mathrm{SO}_{4}^{2-} \mathrm{cm}^{-3} \mathrm{~d}^{-1}$ at $\mathrm{pH}_{\text {opt }}$ of 6.0 (Figure $4 \mathrm{C}$ ). Rates were significantly different between the tested $\mathrm{pH}$ values $(d f=4$, $F=213.73, P<0.001)$. At $\mathrm{pH} 7.2 \mathrm{SRR}$ showed a decrease from 2.4 to $1.6 \mathrm{nmol} \mathrm{SO}_{4}^{2-} \mathrm{cm}^{-3} \mathrm{~d}^{-1}$. In these sediment samples a steep decrease in SRR was observed at $\mathrm{pH}$ values $<6$, reaching $0.7 \mathrm{nmol}$ $\mathrm{SO}_{4}^{2-} \mathrm{cm}^{-3} \mathrm{~d}^{-1}$ at $\mathrm{pH} 5.5$ and $0.1 \mathrm{nmol} \mathrm{SO}_{4}^{2-} \mathrm{cm}^{-3} \mathrm{~d}^{-1}$ at pH 5.0.
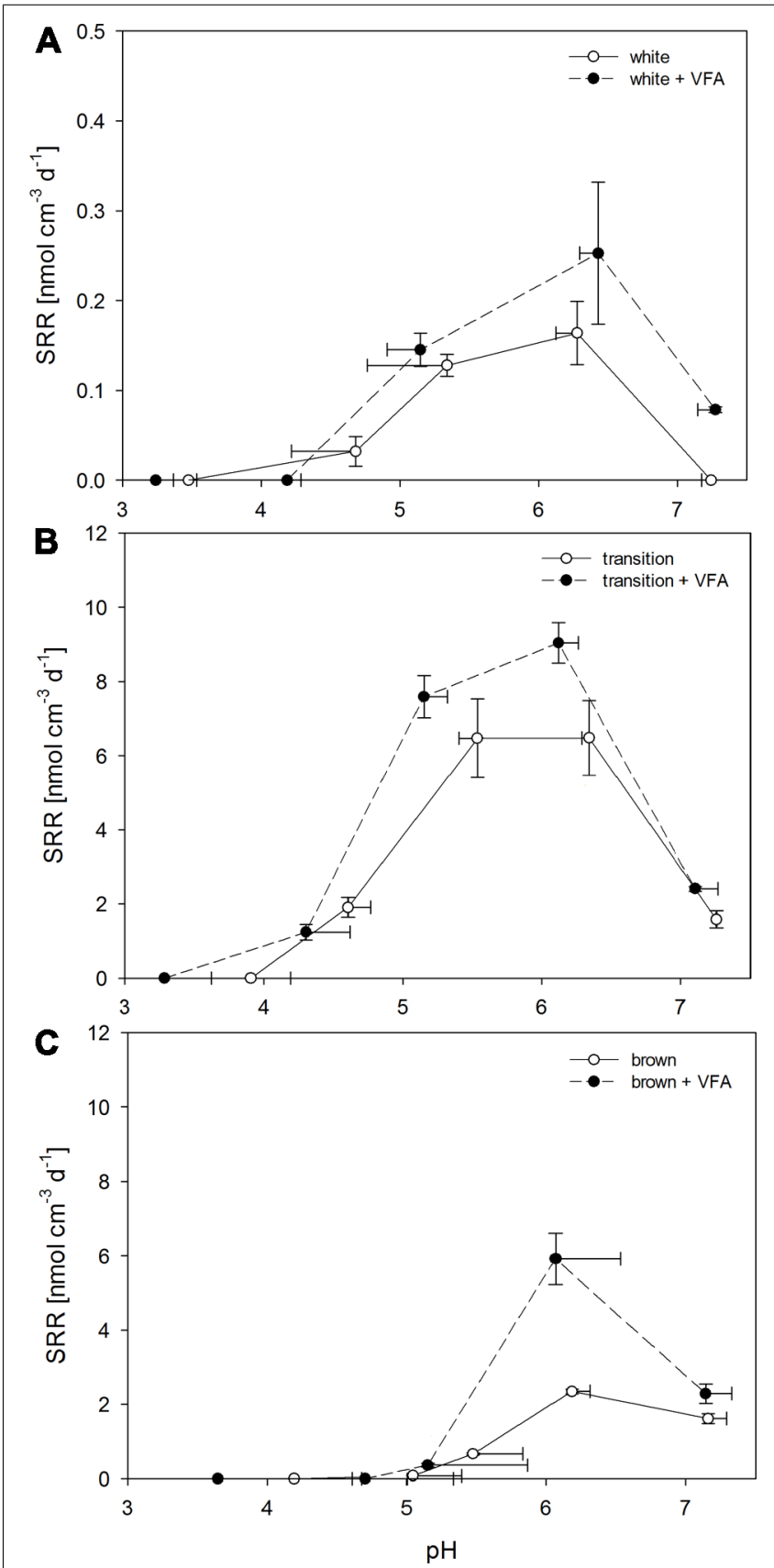

FIGURE 4 | Sulfate reduction rates after incubations for $16 \mathrm{~h}$ of Paleochori Bay, white, transition, and brown zone sediment incubated in not amended and VFA-supplemented media as a function of $\mathrm{pH}$. Incubation temperature was $40^{\circ} \mathrm{C}$. Horizontal error bars show development of $\mathrm{pH}$ value over time of incubation. Vertical error bars show the standard errors of rates $(n=3)$. (A) White zone sediment. (B) Transition zone sediment. (C) Brown zone sediment.

At $\mathrm{pH}<5$, SRR were below the detection limit. VFA amendment resulted in a significant increase $(d f=1, F=26.06, P<0.001)$ and a different response as compared to the other sediments. The $\mathrm{pH}_{\mathrm{opt}}$ was 6.1 as was the case in the non-amended samples and the SRR increased from $2.3 \mathrm{nmol} \mathrm{SO}{ }_{4}^{2-} \mathrm{cm}^{-3} \mathrm{~d}^{-1}$ with no amendment 
to $5.9 \mathrm{nmol} \mathrm{SO} \mathrm{SO}_{4}^{2-} \mathrm{cm}^{-3} \mathrm{~d}^{-1}$ after VFA-addition. At $\mathrm{pH} 7$ only a slight increase in SRR from $1.6 \mathrm{nmol} \mathrm{SO}{ }_{4}^{2-} \mathrm{cm}^{-3} \mathrm{~d}^{-1}$ without amendment to $2.3 \mathrm{nmol} \mathrm{SO} 2-\mathrm{cm}^{-3} \mathrm{~d}^{-1}$ at after amendment was observed.

\section{THE $\mathrm{pCO}_{2}$ EFFECT ON SULFATE REDUCTION}

The different $\mathrm{pCO}_{2}$ partial pressures resulted in different pore water $\mathrm{pH}$ values in sediment samples obtained from the Paleochori Bay sites. In all sediment types a decreasing trend in SRR was observed with increasing $\mathrm{pCO}_{2}$ (Figures 5A-C). A stimulation of SRR upon VFA amendment was observed for all sediment types at a $\mathrm{pCO}_{2}$ of 1 bar. However, the rates decreased with increasing $\mathrm{pCO}_{2}$ after VFA addition and were significantly different for the transition $(d f=2, F=31.51, P<0.001)$ and the brown zone sediment $(d f=2, F=19.68, P=0.002)$. We observed a steep decrease of SRR in all samples after the $\mathrm{CO}_{2}$ gas pressure was increased from 2 to 3 bar even though the $\mathrm{pH}$ only decreased slightly, from 4.8 to 4.7 for the white zone sediment, from 4.7 to 4.6 for transition zone sediment and from 5.5 to 5.4 for the brown zone sediment (Figures 5A-C).

The sediment samples showed different buffering capacities, which were expressed as the relation between $\mathrm{pCO}_{2}$ and subsequent $\mathrm{pH}$ decrease (Figure 6). The pore water of white zone sediment had an intermediate buffering capacity expressed by a $\mathrm{pH}$ decrease from 5.6 to 4.7 after addition of 3 bar of $\mathrm{pCO}_{2}$. The pore water of transition zone sediment had the lowest buffering capacity since the $\mathrm{pH}$ decreased from 5.5 to 4.4 after addition of 3 bar $\mathrm{pCO}_{2}$. The highest $\mathrm{pH}$ value and buffering capacity was found in samples from the brown zone sediment which decreased from 6.1 to 5.2 after $\mathrm{pCO}_{2}$ adjustment (Figure 6).

\section{DISCUSSION}

In this study, the highest SRR without VFA amendment were measured in the brown zone sediment with $35 \mathrm{nmol} \mathrm{SO}_{4}^{2-} \mathrm{cm}^{-3} \mathrm{~d}^{-1}$. SRR determined in these control sediment samples were close to rates reported from temperate regions. For example, Jørgensen and Bak (1991) reported SRR between 5 and $20 \mathrm{nmol}$ $\mathrm{SO}_{4}^{2-} \mathrm{cm}^{-3} \mathrm{~d}^{-1}$ from marine sediments of Kattegat, Denmark. Dando et al. (1995) studied a neighboring hydrothermal vent site in Paleochori Bay at a water depth of $10 \mathrm{~m}$ and determined SRR of between 5 and $80 \mathrm{nmol} \mathrm{SO} \mathrm{Sm}^{2-} \mathrm{cm}^{-3} \mathrm{~d}^{-1}$ applying a radiotracer method (Dando et al., 1991) immediately after sampling. SRR peaked at $2 \mathrm{~cm}$ sediment depth with maximal rates of up to of $80 \mathrm{nmol} \mathrm{SO} \mathrm{SO}_{4}^{2-} \mathrm{cm}^{-3} \mathrm{~d}^{-1}$, which were probably supported by residual organic carbon (Dando et al., 1995) and/or hydrogen gas from the vent fluids. The overall lowered rates in our sediment samples were most likely a consequence of electron donor limitation as the experiments could not be performed immediately after sampling. Intermediate activity was found in surface samples of transition zone sediment with a SRR of $24 \mathrm{nmol} \mathrm{SO}{ }_{4}^{2-} \mathrm{cm}^{-3} \mathrm{~d}^{-1}$. SRR in brown and transition zone sediment were in the range of SR determined in deep-sea hydrothermal vent sediments (19$\left.61 \mathrm{nmol} \mathrm{SO}_{4}^{2-} \mathrm{cm}^{-3} \mathrm{~d}^{-1}\right)$ with in situ temperatures $>100^{\circ} \mathrm{C}$ (Jørgensen etal., 1992) but below the rates measured for the Logatchev hydrothermal field at the Mid Atlantic Ridge with 122$136 \mathrm{nmol} \mathrm{SO}_{4}^{2-} \mathrm{cm}^{-3} \mathrm{~d}^{-1}$ at temperatures between 65 and $100^{\circ} \mathrm{C}$
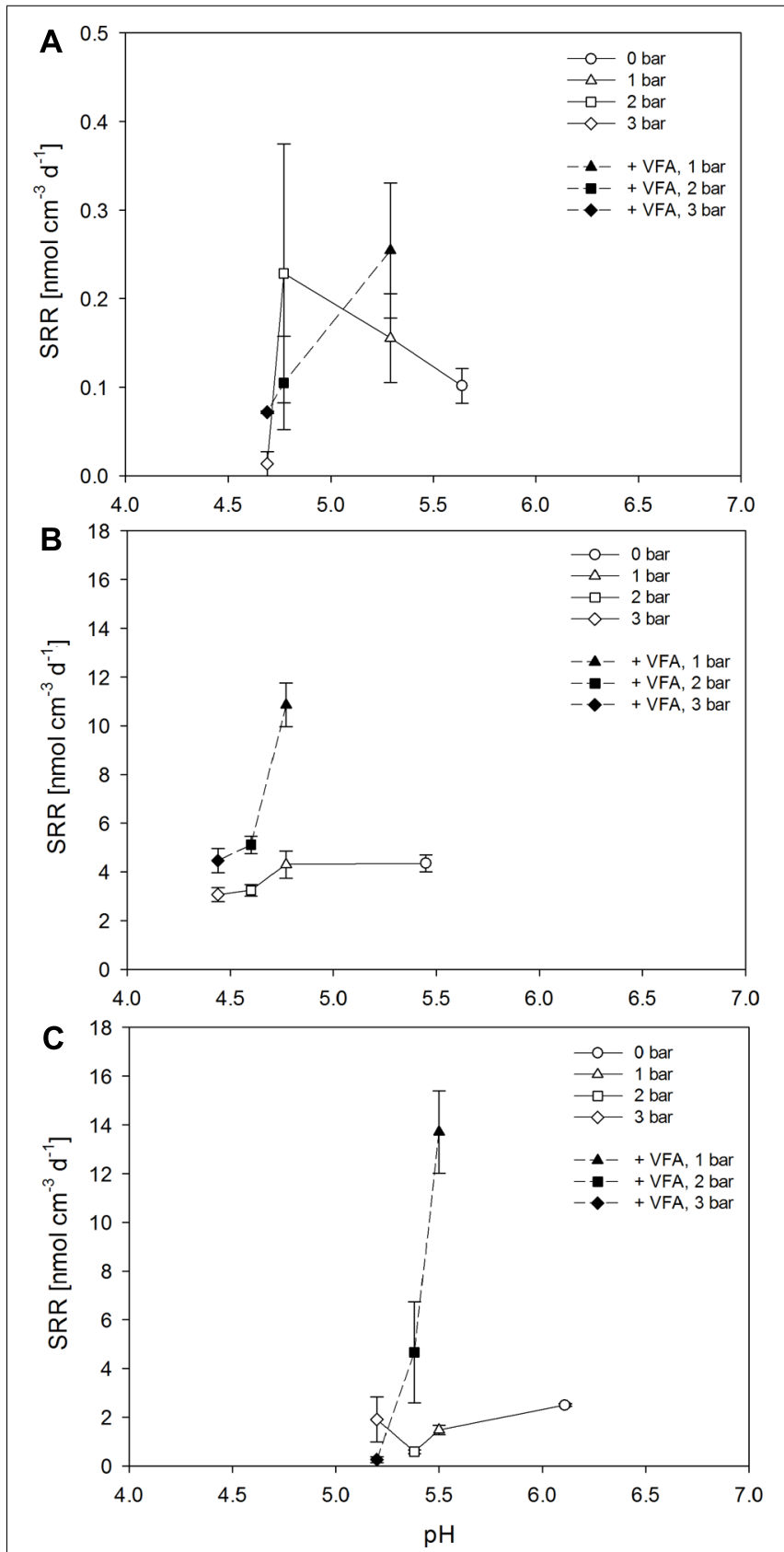

FIGURE 5 | Sulfate reduction rates after incubations for $16 \mathrm{~h}$ of Paleochori Bay, white (A), transition (B), and brown zone sediment (C) incubated in not amended and VFA-supplemented media as a function

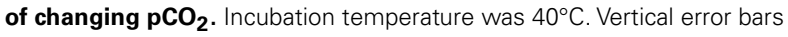
show the standard errors of rates $(n=3)$. Symbols represent different $\mathrm{pCO}_{2}$ conditions, starting with circles for no $\mathrm{pCO}_{2}$, triangles for 1 bar, squares for 2 bar, and diamonds for 3 bar.

(Schauer et al., 2011). The lowest SRR was measured in the white zone sediment. There, SRR were below $1 \mathrm{nmol} \mathrm{SO}{ }_{4}^{2-} \mathrm{cm}^{-3} \mathrm{~d}^{-1}$ after incubation at $40^{\circ} \mathrm{C}$ and below detection limit when the samples were incubated at $75^{\circ} \mathrm{C}$, which is the in situ temperature at $10 \mathrm{~cm}$ sediment depth. The low SRR in the white zone may be due 


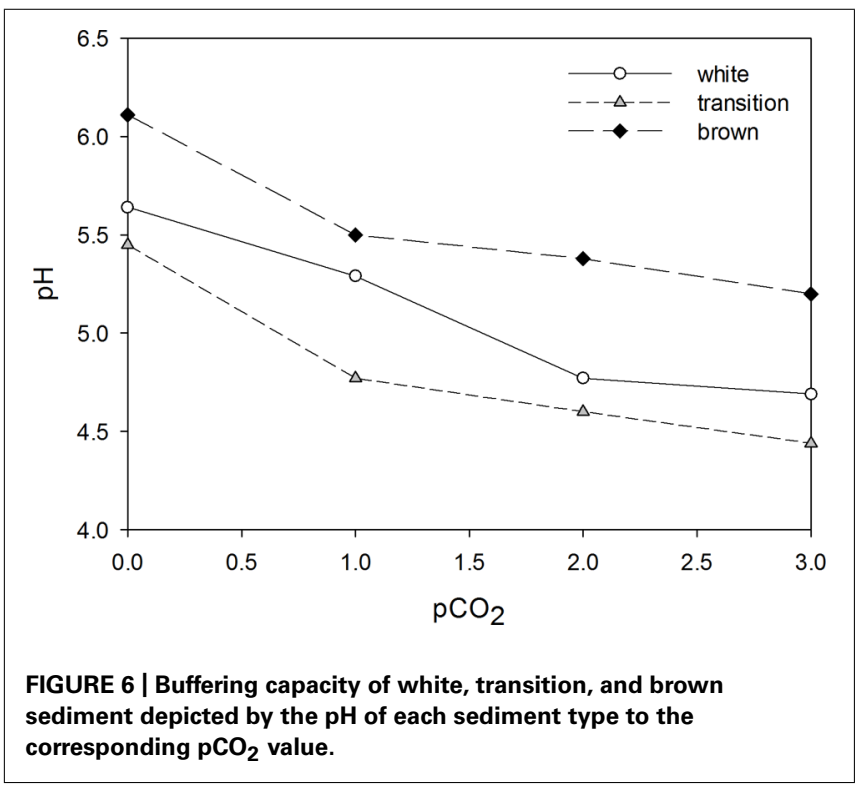

to substrate limitation, in particular lack of hydrogen gas from venting fluids.

The SRB are found in several phylogenetic groups, but mostly belong to the Deltaproteobacteria (e.g., 23 out of 60 genera), followed by the Firmicutes (Muyzer and Stams, 2008; Barton and Fauque, 2009). It is possible that the low SRR, especially in the white zone sediments, may be due to a smaller population size of SRB, at least relative to our other sediment types. Sievert et al. (1999) found mainly Cyanobacteria and sulfur oxidizing Thiomicrospira spp in a hydrothermal vent system that is located close to our study site. Our sediments were collected from a slightly higher temperature, $75^{\circ} \mathrm{C}$ at $10 \mathrm{~cm}$ depth, whereas the white zone temperatures for Sievert et al. (1999) study reached only $50^{\circ} \mathrm{C}$ at $5 \mathrm{~cm}$ sediment depth. Even if polymerase chain reaction (PCR) biases cannot be excluded, the elevated numbers of $16 \mathrm{~S}$ rRNA sequences affiliated with the Deltaproteobacteria, to which most SRB belong, found in the transition and brown zone sediments (Sievert et al., 1999) are in agreement with our results as we found the highest SRR in these sediments.

In a more quantitative study, $16 \mathrm{~S}$ rRNA clone libraries and phylogenetic data were obtained for samples collected in the same area and temperature as this study (Price et al., 2013, this issue). In the white zone with equivalent temperatures to our study, 7 out of 51 clones were obtained for the Deltaproteobacteria in a $0-1.5 \mathrm{~cm}$ sediment depth, whereas none were found in the deeper 3-4.5 and 9-10.5 cm layers. Four out of those seven clones were affiliated with the order Desulfobacterales, one of the major groups known for SR (Muyzer and Stams, 2008). Price et al. (2013, this issue) also reported that members of the Firmicutes phylum became dominant in the deeper sediments, but were exclusively associated with Bacillus sp (at $\sim 100 \%$ ID). In a pooled 0-6 cm sample from a lower temperature $\left(\sim 45^{\circ} \mathrm{C}\right)$ white zone at the same site as this study, 24 out of 119 clones were affiliated with Deltaproteobacteria, 12 of which were associated with the Desulfobacterales order. In pooled 0-6 cm sample from a nearby background brown area, 10 out of 97 clones were affiliated with Desulfobacterales. Thus, in pooled samples of brown zone sediment, about $10 \%$ of the clones in the clone libraries affiliate with groups with the most potential for $\mathrm{SO}_{4}^{2-}$ reduction, while $10 \%$ affiliated with $\mathrm{SRBs}$ in white zone sediments. In the $0-1.5 \mathrm{~cm}$ sediment sample, the contribution of $16 \mathrm{~S}$ rDNA affiliated with SRB was $8 \%$. Due to the small size of the libraries we do not consider the ratios to significantly different among sites. In future studies the microbial diversity in general and that of sulfate reducers should be addressed with next generation sequencing methods (Frank et al., 2013).

A possible explanation for the low SRR in white zone sediment could also be its high spatial instability due to transport of gas, venting and mixing in combination with oxygenation of the sediment layers which could lead to a removal of microorganisms. Mixing might also disturb the coupling between fermenters and sulfate reducers, which thrive on oxidizing fermentation products such as VFA and $\mathrm{H}_{2}$. Finke and Jørgensen (2008) observed that temperature had an effect on the coupling between fermentation and SR in sediment samples from Svalbard and Wadden Sea as fermentation products accumulated in incubations above a critical temperature of $40^{\circ} \mathrm{C}$. The authors concluded that temperature is a factor that might disturb the metabolic link between both process types because sulfate reducers were inhibited at a lower critical temperature than fermenters (Finke and Jørgensen, 2008). In our study, a higher threshold for negative temperature effects is expected as the natural temperatures of the hydrothermal vent system ranged from 26 to $75^{\circ} \mathrm{C}$. Effects that reduce SRR can most likely be attributed to low $\mathrm{pH}$ leading to a protonation of acid anions, which short-cuts proton gradients in the cells and disrupts adenosine triphosphate (ATP) synthesis (Baronofsky et al., 1984).

\section{THE pH EFFECT ON SULFATE REDUCTION}

Based on cell culture studies, it was suggested that SR may preferentially occur at $\mathrm{pH}$ between 6 and 8 (Widdel, 1988; Hao et al., 1996). However, Dando et al. (1995) have documented that SR can take place at high rates in shallow submarine hydrothermal vent systems with low $\mathrm{pH}$. Our results are in line with those reported by Dando et al. (1995), and demonstrate that hydrothermal sediments with lower $\mathrm{pH}$ and increased temperature harbor populations of SRB that respond distinctly to different $\mathrm{pH}$ conditions. In addition, our data indicate that hydrothermal sediments had different $\mathrm{pH}$ optima than SR populations of sediments with low temperature and neutral to slightly alkaline $\mathrm{pH}$ characteristics. We observed SR at $\mathrm{pH}<5$ in hydrothermally influenced, $\mathrm{CO}_{2}-$ vented sediments. However, optimal $\mathrm{pH}$ of $\mathrm{SR}$ was found between pH 5 and 6 for the hydrothermally influenced white and transition zone sediments but between $\mathrm{pH}$ 6-7 for brown zone sediment that served as control.

Sulfate reducing activity under low $\mathrm{pH}$ conditions is often explained by the existence of microenvironments with more reduced and alkaline conditions than the acidic surroundings (Fortin, 1996). Koschorreck (2008) argued against the existence of neutral microniches formed by the alkalinity produced during SR. He calculated that a SRR of $1.8 \times 10^{8} \mathrm{nmol} \mathrm{SO}_{4}^{2-} \mathrm{cm}^{-3} \mathrm{~d}^{-1}$ is required to maintain circumneutral $\mathrm{pH}$ in a sphere with $100 \mu \mathrm{m}$ diameter while the $\mathrm{pH}$ in the surrounding is 3. Applying this calculation to the hydrothermal vent sediments of Paleochori Bay, 
a SRR of $1.6 \times 10^{6} \mathrm{nmol} \mathrm{SO}{ }_{4}^{2-} \mathrm{cm}^{-3} \mathrm{~d}^{-1}$ would be needed to maintain the center of the sphere at $\mathrm{pH} 6$ when the $\mathrm{pH}$ of the surrounding pore water was 5 . This rate exceeds the SRR in the hydrothermal vent system of Paleochori Bay by five to six orders of magnitude and supports our argument that SRB populations are adapted to low $\mathrm{pH}$ rather than the presence of neutral microsites.

In previous studies, it was suggested that sulfate reducers are more susceptible to high VFA concentrations than methanogens (James et al., 1998), which might result in a shift from SR to methanogenesis at low pH (Koschorreck, 2008). A study on methanogenesis in a bioreactor at $\mathrm{pH}$ of 4.5 showed a $30 \%$ increase of methane yield as compared to neutral conditions, after a slow acclimation of the methanogens to lowered $\mathrm{pH}$ (Taconi et al., 2008). A competition between sulfate reducers and methanogens due to diluted sulfate concentrations by the vent outflow and higher susceptibility of the sulfate reducing community to low $\mathrm{pH}$, can be excluded as the abundance of Archaea as well as their diversity was low in white and brown zone sediments (Nitzsche, 2010; Price et al., 2013, this issue).

\section{THE EFFECT OF VOLATILE FATTY ACIDS ON SULFATE REDUCTION AT LOW pH}

Protonated short-chained fatty acids diffuse through the cell membrane and consequently act as protonophores and as uncoupling agents (Kell etal., 1981). This is not the case for their conjugate anions, which are excluded by their physical properties and charged head groups of lipids from the biological bilayer. Small fatty acids turn lipophilic under acidic conditions depending on their dissociation constant $\mathrm{pK} a$, pass through membranes by passive diffusion and destruct the gradients ( $\mathrm{pH}$ gradient, $\Delta \mathrm{pH}$ and membrane potential $\Delta \Psi$ ) necessary for ATP synthesis and transport function. In addition, they acidify the intrinsic circumneutral cytoplasm of the cell by dissociation and proton release. The reduced cytoplasmic $\mathrm{pH}$ inhibits cellular reactions and energy conservation triggered by proton-motive force (Baronofsky et al., 1984). With the formula:

$$
[\mathrm{Ac}] /[\mathrm{HAc}]=10^{\mathrm{pH}-\mathrm{pKa}}
$$

where [Ac] equals the total acid concentration and [HAc] the amount of protonated acid at a certain $\mathrm{pH}$ and the $\mathrm{pKa}$ values of a total concentration of $1 \mathrm{mmol} \mathrm{L}^{-1} \mathrm{VFA}$ (formate, acetate, propionate, butyrate, and succinate) with $\mathrm{pKa}$ values of 3.75; $4.76 ; 4.87 ; 4.81 ; 4.16$ (Perrin, 1972) in the slurry we can calculate the concentration of protonated fatty acids (Bruun et al., 2010) at $\mathrm{pH}$ values from 3 to 7 . The total concentration of protonated organic acids of the VFA in the slurry is $43.3 \mathrm{mmol} \mathrm{L}^{-1}$ at $\mathrm{pH}$ of 3; $4.3 \mathrm{mmol} \mathrm{L}^{-1}$ at $\mathrm{pH} 4,0.4 \mathrm{mmol} \mathrm{L}^{-1}$ at $\mathrm{pH} 5 ; 0.01 \mathrm{mmol} \mathrm{L}^{-1}$ at $\mathrm{pH} 6$ and negligible for a $\mathrm{pH} 7\left(0.004 \mathrm{mmol} \mathrm{L}^{-1}\right)$. In this study, only the protonated fatty acid concentration at $\mathrm{pH}$ values of 3 and 4 might become harmful to SRB (Baronofsky et al., 1984). This is consistent with our $\mathrm{pH}$-experiment data in which the SRR of the VFA-amended slurry is lower than the rate measured in unamended sediment of white and transition zone sediment at $\mathrm{pH}<5$. At $\mathrm{pH} 6.4$, the SRR measured after VFA addition to white zone sediment $\left(0.3 \mathrm{nmol} \mathrm{SO} \mathrm{SO}_{4}^{2-} \mathrm{cm}^{-3} \mathrm{~d}^{-1}\right)$ exceeded the SRR (0.2 nmol SO $\left.\mathrm{SO}_{4}^{2-} \mathrm{cm}^{-3} \mathrm{~d}^{-1}\right)$ at a similar $\mathrm{pH}(\mathrm{pH} \mathrm{6.3)}$ without addition. In brown zone sediment slurries, the limit for VFA stimulation was equal to unamended sediment at $\mathrm{pH}$ 5.5. The SRR at $\mathrm{pH} 6.2$ of $2.3 \mathrm{nmol} \mathrm{SO}{ }_{4}^{2-} \mathrm{cm}^{-3} \mathrm{~d}^{-1}$ was stimulated by VFA amendment to a rate of $5.9 \mathrm{nmol} \mathrm{SO} \mathrm{SO}^{2-} \mathrm{cm}^{-3} \mathrm{~d}^{-1}$. A $\mathrm{SRR}$ increase was also observed at neutral $\mathrm{pH}$ for brown zone sediments: here SRR increased from $1.6 \mathrm{nmol} \mathrm{SO} \mathrm{SO}_{4}^{2-} \mathrm{cm}^{-3} \mathrm{~d}^{-1}$ without amendment to $2.3 \mathrm{nmol} \mathrm{SO}{ }_{4}^{2-} \mathrm{cm}^{-3} \mathrm{~d}^{-1}$ in amended slurries. Since VFA were added as a mixture to the slurries, no further differentiation between the individual fatty acids on SRR was possible. The presented results are consistent with studies on activity inhibition caused by organic acids at artificially lowered pH (Ottosen et al., 2009) and fresh water seep systems (Bruun et al., 2010).

\section{THE EFFECT OF $\mathrm{pCO}_{2}$ ON SULFATE REDUCTION}

The content of $\mathrm{CO}_{2}$ correlates with $\mathrm{pH}$. Dissolved $\mathrm{CO}_{2}$ reacts with water to form carbonic acid $\left(\mathrm{H}_{2} \mathrm{CO}_{3}\right)$, which immediately dissociates to bicarbonate $\left(\mathrm{HCO}_{3}{ }^{-}\right)$and protons $\left(\mathrm{H}^{+}\right) . \mathrm{HCO}_{3}{ }^{-}$ and $\mathrm{H}^{+}$can further dissociate to $\mathrm{CO}_{3}^{2-}$ and $\mathrm{H}^{+}$decreasing the $\mathrm{pH}$ in the solution. In this context, "carbonic acid" encompasses the species $\mathrm{CO}_{2}, \mathrm{H}_{2} \mathrm{CO}_{3}, \mathrm{HCO}_{3}^{-}$, and $\mathrm{CO}_{3}^{2-}$ (Zeebe and Wolf-Gladrow, 2001). The existence of the different carbonic acid species depends on their concentrations, dissociation constants and $\mathrm{pH}$ as described by the Bjerrum plot (Zeebe and Wolf-Gladrow, 2001).

In this study, the relation between $\mathrm{pH}$ and SRR relative to different $\mathrm{pCO}_{2}$ was examined. This is of particular interest in order to understand microbial functioning in $\mathrm{CO}_{2}$ - venting sediments which are perfect natural laboratories for studies focused on $\mathrm{CO}_{2}$ sequestration in which carbon dioxide is removed from the atmosphere and stored in sediments that should serve as longterm reservoirs (Shitashima et al., 2008). After adjustment of the $\mathrm{CO}_{2}$ partial pressure to $0,1,2$, and $3 \mathrm{bar}$, we found that a $\mathrm{pCO}_{2}$ increase resulted in different $\mathrm{pH}$ values among the sediment types. This may be a consequence of different chemical and biological buffering capacities of the sediment (Heijs et al., 1999). The mineral characteristics of the sediment (e.g., silicate, carbonate) and the bicarbonate content of the seawater dictate chemical buffering capacity of the sediment. The addition of $\mathrm{CO}_{2}$ results in a decrease in $\mathrm{pH}$ (Zeebe and Wolf-Gladrow, 2001). SR produces bicarbonate alkalinity and consequently counteracts a decrease of $\mathrm{pH}$. The data obtained from $\mathrm{pCO}_{2}$ incubation experiments provide a rough indication of the buffering capacity of the Paleochori Bay sediments: the brown zone sediment has the highest buffering capacity followed by white and finally transition zone sediments. This was also obvious from the amounts of phosphoric acid needed to decrease the $\mathrm{pH}$ in the $\mathrm{pH}$ experiments (data not shown).

Sulfate reduction rates responded to increase in $\mathrm{pCO}_{2}$ with a decrease in activity in nearly all experiments although effect of an increase in $\mathrm{pCO}_{2}$ from 2 to 3 bar on $\mathrm{pH}$ was negligible. A $\mathrm{pCO}_{2}$ increase from 1 to 2 bar reduced SRR from 0.2 to $0.1 \mathrm{nmol}$ $\mathrm{SO}_{4}^{2-} \mathrm{cm}^{-3} \mathrm{~d}^{-1}$ in the white zone sediment slurries, from 4.3 to $3.2 \mathrm{nmol} \mathrm{SO}_{4}^{2-} \mathrm{cm}^{-3} \mathrm{~d}^{-1}$ in transition zone slurries and from 1.5 to $0.6 \mathrm{nmol} \mathrm{SO}_{4}^{2-} \mathrm{cm}^{-3} \mathrm{~d}^{-1}$ for the brown zone sediment 
slurries. The increase in $\mathrm{pCO}_{2}$ was accompanied by $\mathrm{pH}$ changes from 4.8 to $4.7,4.8$ to 4.6 and 5.5 to 5.4 in the three sediments, respectively. The effect of SRR reduction upon $\mathrm{pCO}_{2}$ increase was even stronger after VFA were added to the slurries (Figure 5). In our experiments we observed similar effects as in Debs-Louka et al. (1999) concluding that the reduction in $\mathrm{pH}$ due to increasing $\mathrm{pCO}_{2}$ was not sufficient to account for antimicrobial activity. In this study microbial inactivation depended strongly on $\mathrm{CO}_{2}$ partial pressure (tested for 15-55 bar), exposure time, the decompression time and water content of the sample. A sudden increase in $\mathrm{pCO}_{2}$ was observed to provoke cell ruptures and lead to reduced bacterial numbers (Debs-Louka et al., 1999). Additionally, it can be suggested that the content of $\mathrm{CO}_{2}$ in the form of carbonic acid has a negative effect on the cell as it can permeate the membrane and dissociate in $\mathrm{CO}_{3}^{2-}$ and $\mathrm{H}^{+}$in the circumneutral cytoplasm, decreasing the intrinsic $\mathrm{pH}$ of the cell.

\section{CONCLUSION}

We observed a significant difference between SR in hydrothermally influenced and background sediments suggesting that microbial communities are adapted to low $\mathrm{pH}$ in the hydrothermal sediments of Milos. Sulfate reducing communities in hydrothermal sediments showed $\mathrm{pH}$ activity optima between 5 and 6 . In contrast, SR in sediments with no hydrothermal influence exhibited

\section{REFERENCES}

Amend, J., Rogers, K., and MeyerDombard, D. (2004). Microbially mediated sulfur -redox: energetics in marine hydrothermal vent systems. Geol. Soc. Am. 379, 17-34.

Baker-Austin, C., and Dopson, M. (2007). Life in acid: $\mathrm{pH}$ homeostasis in acidophiles. Trends Microbiol. 15, 165-171.

Baronofsky, J. J., Schreurs, W. J., and Kashket, E. R. (1984). Uncoupling by acetic acid limits growth of and acetogenesis by Clostridium thermoaceticum. Appl. Environ. Microbiol. 48, 1134-1139.

Barton, L. L., and Fauque, G. D. (2009). Biochemistry, physiology and biotechnology of sulfate-reducing bacteria. Adv. Appl. Microbiol. 68, 41-98.

Bruun, A. M., Finster, K., Gunnlaugsson, H. P., Nürnberg, P., and Friedrich, M. W. (2010). A comprehensive investigation on iron cycling in a freshwater seep including microscopy, cultivation and molecular community analysis. Geomicrobiol. J. 27, 15-34.

Cline, J. D. (1969). Spectrophotometric determination of hydrogen sulfide in natural waters. Limnol. Oceanogr. 14, 454-458.

Dando, P. R., Austen, M. C., Burke, R. A., Kendall, M. A., Kennicutt, M.C. II., Judd, A.G., et al. (1991). Ecology of a North Sea pockmark with an active methane seep. Mar. Ecol. Prog. Ser. $70,49-63$.
Dando, P. R., Hughes, J. A., Leahy, Y., Niven, S. J., Taylor, L. J., and Smith, C. (1995). Gas venting rates from submarine hydrothermal areas around the island of Milos, Hellenic Volcanic Arc. Cont. Shelf Res. 15 913-929.

Debs-Louka, E., Louka, N., Abraham, G., Chabot, V., and Allaf, K. (1999). Effect of compressed carbon dioxide on microbial cell viability. Appl. Environ. Microbiol. 65, 626-631.

Finke, N., and Jørgensen, B. B. (2008). Response of fermentation and sulfate reduction to experimental temperature changes in temperate and Arctic marine sediments. ISME J. 2, 815-829. J. A., Thiermann, F., Akoumianaki, I., and Pratt, S. M. (1997). Submarine hydrothermal brine seeps off Milos, Greece. Observations and geochemistry. Mar. Chem. 57, 325-340.

Fortin, D. (1996). Role of Thiobacillus and sulfate-reducing bacteria in iron biocycling in oxic and acidic mine tailings. FEMS Microbiol. Ecol. 21, 11-24.

Fossing, H., and Jørgensen, B. B. (1989). Measurement of bacterial sulfate reduction in sediments: evaluation of a single-step chromium reduction method. Biogeochemistry 8, 205-222.

Frank, K. L., Rogers, D. R., Olins, H. C., Vidoudez, C., and Girguis, P. R. (2013). Characterizing
Fitzsimons, M. F., Dando, P. R., Hughes,

$\mathrm{pH}$ optima between 6 and 7. The shallow-sea hydrothermal vent of Paleochori Bay, Milos (Greece) with pH between 5 and 7, temperature range of $26-90^{\circ} \mathrm{C}$ and a high content of dissolved arsenic and sulfide in the sediment pore water, represents an extreme environment in which SR may play an important role in the degradation of organic material. This study suggests that marine microbial SR communities that are specifically adapted to a life at high $\mathrm{pCO}_{2}$ and low $\mathrm{pH}$ do exist.

\section{ACKNOWLEDGMENTS}

This was an International Max Planck Research School of Marine Microbiology (MarMic) project with funding provided by the Max Planck Society. Partial funding for logistics and geochemical analyses was also provided by a University of Bremen MARUM Postdoc Fellowship (to Roy E. Price) and MARUM Incentive Funding (to Roy E. Price and S. Bühring). Thanks to MARUM for providing the possibility to join the Milos Expedition in October 2009 and C.I. Huang for the kind collaboration. We are grateful to the expedition team M.J. Ruíz Chancho, M. Sollich, M. Bausch. Special thanks to A. Godelitsas, A. Vichos, the Artemis Bungalows, and the Sirocco Restaurant for logistical support in Athens and Milos. Thanks to $\mathrm{K}$. Imhoff for the assistance in sulfate measurements and A. Meyerdierks for revision of the manuscript. The manuscript has been greatly improved by the valuable comments of the reviewers.

the distribution and rates of microbial sulfate reduction at Middle Valley hydrothermal vents. ISME J. doi: 10.1038/ismej.2013.17 [Epub ahead of print].

Hao, O. J., Chen, J. M., Huang, L., and Buglass, R. L. (1996). Sulfatereducing bacteria. Crit. Rev. Environ. Sci. Technol. 26, 155-187.

Heijs, S. K., Jonkers, H. M., van Gemerden, H., Schaub, B. E. M., and Stal, L. J. (1999). The buffering capacity towards free sulphide in sediments of a coastal lagoon (Bassin d'Arcachon, France)-the relative importance of chemical and biological processes. Estuar. Coast. Shelf Sci. 49, 21-35.

Hubert, C., Loy, A., Nickel, M., Arnosti, C., Baranyi, C., Brüchert, V., et al. (2009). A constant flux of diverse thermophilic bacteria into the cold Arctic seabed. Science 325, 15411544.

Isaksen, M. F., Bak, F., and Jørgensen, B. B. (1994). Thermophilic sulfatereducing bacteria in cold marine sediment. FEMS Microbiol. Ecol. 14, $1-8$.

James, A. G., Watson-Craik, I. A., and Senior, E. (1998). The effects of organic acids on the methanogenic degradation of the landfill leachate molecules butyrate and valerate. Water Res. 32, 792-800.

Jannasch, H. W., and Mottl, M. J. (1985). Geomicrobiology of deepsea hydrothermal vents. Science 229 $717-725$.
Jørgensen, B. B. (1982). Mineralization of organic matter in the sea bedthe role of sulphate reduction. Nature 296, 643-645.

Jørgensen, B. B., and Bak, F. (1991). Pathways and microbiology of thiosulfate transformations and sulfate reduction in a marine sediment (Kattegat, Denmark). Appl. Environ. Microbiol. 57, 847-856.

Jørgensen, B. B., Isaksen, M. F., and Jannasch, H. W. (1992). Bacterial sulfate reduction above $100^{\circ} \mathrm{C}$ in deep-sea hydrothermal vent sediments. Science 258, 1756-1757.

Kaksonen, A. H., and Puhakka, J. A. (2007). Sulfate reduction based bioprocesses for the treatment of acid mine drainage and the recovery of metals. Eng. Life Sci. 7, 541-564.

Kallmeyer, J., Ferdelman, T. G., Weber, A., Fossing, H., and Jørgensen, B. B. (2004). A cold chromium distillation procedure for radiolabeled sulfide applied to sulfate reduction measurements. Limnol. Oceanogr. 2, 171-180.

Kell, D. B., Peck, M. W., Rodger, G., and Morris, J. G. (1981). On the permeability to weak acids and bases of the cytoplasmic membrane of Clostridium pasteurianum. Biochem. Biophys. Res. Commun. 99, 81-88.

Knoblauch, C., and Jørgensen, B. B. (1999). Effect of temperature on sulphate reduction, growth rate and growth yield in five psychrophilic 
sulphate-reducing bacteria from Arctic sediments. Environ. Microbiol. 1, 457-467.

Koschorreck, M. (2008). Microbial sulphate reduction at a low $\mathrm{pH}$. FEMS Microbiol. Ecol. 64, 329-342.

Lowe, S. E., Jain, M. K., and Zeikus, J. G. (1993). Biology, ecology, and biotechnological applications of anaerobic-bacteria adapted to environmental stresses in temperature, $\mathrm{pH}$, salinity, or substrates. Microbiol. Rev.57, 451-509.

Martin, A. (1990). Bioenergetic parameters and transport in obligate acidophiles. Biochim. Biophys. Acta 1018, 267-270.

Moosa, S., and Harrison, S. T. L. (2006). Product inhibition by sulphide species on biological sulphate reduction for the treatment of acid mine drainage. Hydrometallurgy 83 , 214-222.

Muyzer, G., and Stams, A. J. (2008). The ecology and biotechnology of sulphate-reducing bacteria. Nat. Rev. Microbiol. 6, 441-454.

Nitzsche, K. (2010). Microbial Diversity of Hydrothermally Influenced ArsenicRich Sediments off the Coast of
Milos Island, Greece. thesis, TU Bergakademie, Freiberg, Germany.

Ottosen, L. D. M., Poulsen, H. V., Nielsen, D. A., Finster, K., Nielsen, L. P., and Revsbech, N. P. (2009). Observations on microbial activity in acidified pig slurry. Biosyst. Eng. 102, 291-297.

Perrin, D. D. (1972). Dissociation Constants of Organic Bases in Aqueous Solution. London: Franklin Book Co.

Price, R. E., Savov, I., Planer-Friedrich,

B., Bühring, S., Amend, J., and Pichler, T. (2012). Processes influencing extreme as enrichment in shallow-sea hydrothermal fluids of Milos Island, Greece. Chem. Geol. doi: 10.1016/j.chemgeo.2012.06.007

Price, R. P., Nitzsche, K., Lesniewski, R., Meyerdierks, A., Saltikov, C., Edwards, K., et al. (2013, this issue). Microbial diversity and arsenic metabolism in depth profiles from a shallow-sea hydrothermal vent system undergoing phase separation; Milos Island (Greece). (this issue).

Schauer, R., Røy, H., Augustin, N. Gennerich, H. H., Peters, M., Wenzhoefer, F., et al. (2011). Bacterial sulfur cycling shapes microbial communities in surface sediments of an ultramafic hydrothermal vent field. Environ. Microbiol. 13, 2633-2648.

Shitashima, K., Maeda, Y., Koike, Y., and Ohsumi, T. (2008). Natural analogue of the rise and dissolution of liquid $\mathrm{CO}_{2}$ in the ocean. Int. J. Greenh. Gas Con. 2, 95-104.

Sievert, S. M., Brinkhoff, T., Muyzer, G., Ziebis, W., and Kuever, J. (1999). Spatial heterogeneity of bacterial populations along an environmental gradient at a shallow submarine hydrothermal vent near Milos Island (Greece). Appl. Environ. Microbiol. 65, 3834-3842.

Taconi, K. A., Zappi, M. E., French, W. T., and Brown, L. R. (2008) Methanogenesis under acidic $\mathrm{pH}$ conditions in a semi-continuous reactor system. Bioresour. Technol. 99, 8075-8081.

Widdel, F. (1988). "Microbiology and ecology of sulfate and sulfurreducing bacteria," in Biology of Anaerobic Microorganisms ed. A. J. B. Zehnder (New York: John Wiley), 469-586.

Zeebe, R. E., and Wolf-Gladrow, D. (2001). $\mathrm{CO}_{2}$ in Seawater: Equilib rium, Kinetics, Isotopes. Amsterdam Elsevier Oceanography Book Series.
Conflict of Interest Statement: The authors declare that the research was conducted in the absence of any commercial or financial relationships that could be construed as a potential conflict of interest.

Received: 28 January 2013; accepted: 17 April 2013; published online: 08 May 2013.

Citation: Bayraktarov E, Price RE, Ferdelman TG and Finster $K$ (2013) The $p H$ and $p \mathrm{CO}_{2}$ dependence of sulfate reduction in shallow-sea hydrothermal $\mathrm{CO}_{2}$ - venting sediments (Milos Island, Greece). Front. Microbiol. 4:111. doi: 10.3389/fmicb.2013.00111

This article was submitted to Frontiers in Extreme Microbiology, a specialty of Frontiers in Microbiology.

Copyright () 2013 Bayraktarov, Price, Ferdelman and Finster. This is an openaccess article distributed under the terms of the Creative Commons Attribution License, which permits use, distribution and reproduction in other forums, provided the original authors and source are credited and subject to any copyright notices concerning any third-party graphics etc. 